\title{
Spatiotemporal temperature variations in the East China Sea shelf during the Holocene in response to surface circulation evolution
}

\author{
Zineng Yuan ${ }^{\mathrm{a}, \mathrm{c}}$, Xiaotong Xiao ${ }^{\mathrm{a}, \mathrm{b}, *}$, Fei Wang $^{\mathrm{a}}$, Lei Xing ${ }^{\mathrm{a}, \mathrm{b}}$, Zicheng Wang ${ }^{\mathrm{a}, \mathrm{b}}$, Hailong Zhang ${ }^{\mathrm{a}, \mathrm{b}}$, \\ Rong Xiang ${ }^{\mathrm{d}}$, Liping Zhou ${ }^{\mathrm{b}, \mathrm{e}}$, Meixun Zhao ${ }^{\mathrm{a}, \mathrm{b}, * *}$ \\ ${ }^{a}$ Key Laboratory of Marine Chemistry Theory and Technology of the Ministry of Education, Ocean University of China, Qingdao 266100, China \\ ${ }^{\mathrm{b}}$ Laboratory for Marine Ecology and Environmental Science, Qingdao National Laboratory for Marine Science and Technology, Qingdao 266061, China \\ ${ }^{c}$ Key Laboratory of Coastal Zone Environmental Processes and Ecological Remediation, Yantai Institute of Coastal Zone Research, Chinese Academy of Sciences/Shandong \\ Provincial Key Laboratory of Coastal Zone Environmental Processes, Yantai 264003, China \\ d Key Laboratory of Marginal Sea Geology, South China Sea Institute of Oceanology, Chinese Academy of Sciences, Guangzhou 510301, China \\ e Laboratory for Earth Surface Processes, Department of Geography, and Institute of Ocean Research, Peking University, Beijing 100871, China
}

\section{A R T I C L E I N F O}

\section{Keywords:}

Holocene

Ocean circulation

Temperature structure

$U_{37}^{K^{\prime}}$

$\mathrm{TEX}_{86}$

East China Sea

\begin{abstract}
A B S T R A C T
The Holocene environment evolution in the East China Sea (ECS) is characterized by the gradual establishment and strengthening of its shelf circulation system, but knowledge about temperature responses in temporal and spatial scales is limited due to the lack of continuous high-resolution records. Here, we compare $U_{37}^{K^{\prime}}$ and $\mathrm{TEX}_{86}$ temperature records for three cores from the ECS shelf, which provide the temporal and spatial patterns of Holocene temperature structure variations. These temperature records revealed broadly consistent temporal trends with three intervals characterized by two distinct shifts. During the early Holocene (10.0-6.0 ka), the modern-type circulation system was not established, which resulted in strong water column stratification; and the higher sea surface temperature (SST) might be associated with the Holocene Thermal Maximum (HTM). The interval of 6.0 to 1.0/2.0 ka displayed a weaker stratification caused by the intrusion of the Yellow Sea Warm Current (YSWC) and the initiation of the circulation system. A decreasing SST trend was related to the formation of the cold eddy generated by the circulation system in the ECS. During 1.0/2.0 to $0 \mathrm{ka}$, temperatures were characterized by much weaker stratification and an abrupt decrease of SST caused by the enhanced circulation system and stronger cold eddy, respectively. Thus, the temperature structure in the shelf of ECS was closely related with circulation system changes during the mid-late Holocene, which was most likely driven by the intrusion of Kuroshio Current (KC). The significant asynchrony of temperature decreases in the three locations during the late Holocene was likely caused by the gradual expansion of the ECS cold eddy area.
\end{abstract}

\section{Introduction}

Temperature is an important component of marine ecosystems, and its variations in vertical and horizontal structures are coupled with climate changes, and consequently influence the structure and function of marine ecosystems. It is generally accepted that the overall global temperature during the Holocene had a cooling trend of ca. $0.5^{\circ} \mathrm{C}$ following the Holocene Thermal Maximum (HTM) towards the late Holocene (Marcott et al., 2013). However, the range and timing of the temperature decrease varied substantially between different regions, due to additional forcings and feedbacks (Huang et al., 2011; Jennings et al., 2011; Moossen et al., 2015; Trommer et al., 2010; Warden et al., 2016). Many pieces of evidence demonstrated that the evolution of ocean circulation was an important additional driver for regional temperature variations (Giraudeau et al., 2010; Trommer et al., 2010). Thus, better constraints on temperature response to ocean circulation and global climate forcing are needed to get insight to the regional environment change mechanisms and to understand their ecological influences on marine ecosystems.

The East China Sea (ECS) has received increasing attentions for environmental and ecosystem studies recently (Hu et al., 2014; Xing et al., 2016), because of its unique geographic location and complex hydrography. Located between the world's largest continent and the largest ocean, the ECS is influenced by climatic forcing from both the high-latitude Northern Hemisphere (East Asian Monsoon System) and the tropic ocean (Kuroshio Current, KC), generating distinct seasonal

\footnotetext{
* Corresponding author. Key Laboratory of Marine Chemistry Theory and Technology of the Ministry of Education, Ocean University of China, Qingdao 266100, China.

** Corresponding author. Key Laboratory of Marine Chemistry Theory and Technology of the Ministry of Education, Ocean University of China, Qingdao 266100, China.

E-mail addresses: xtxiao@ouc.edu.cn (X. Xiao), maxzhao@ouc.edu.cn (M. Zhao).
} 


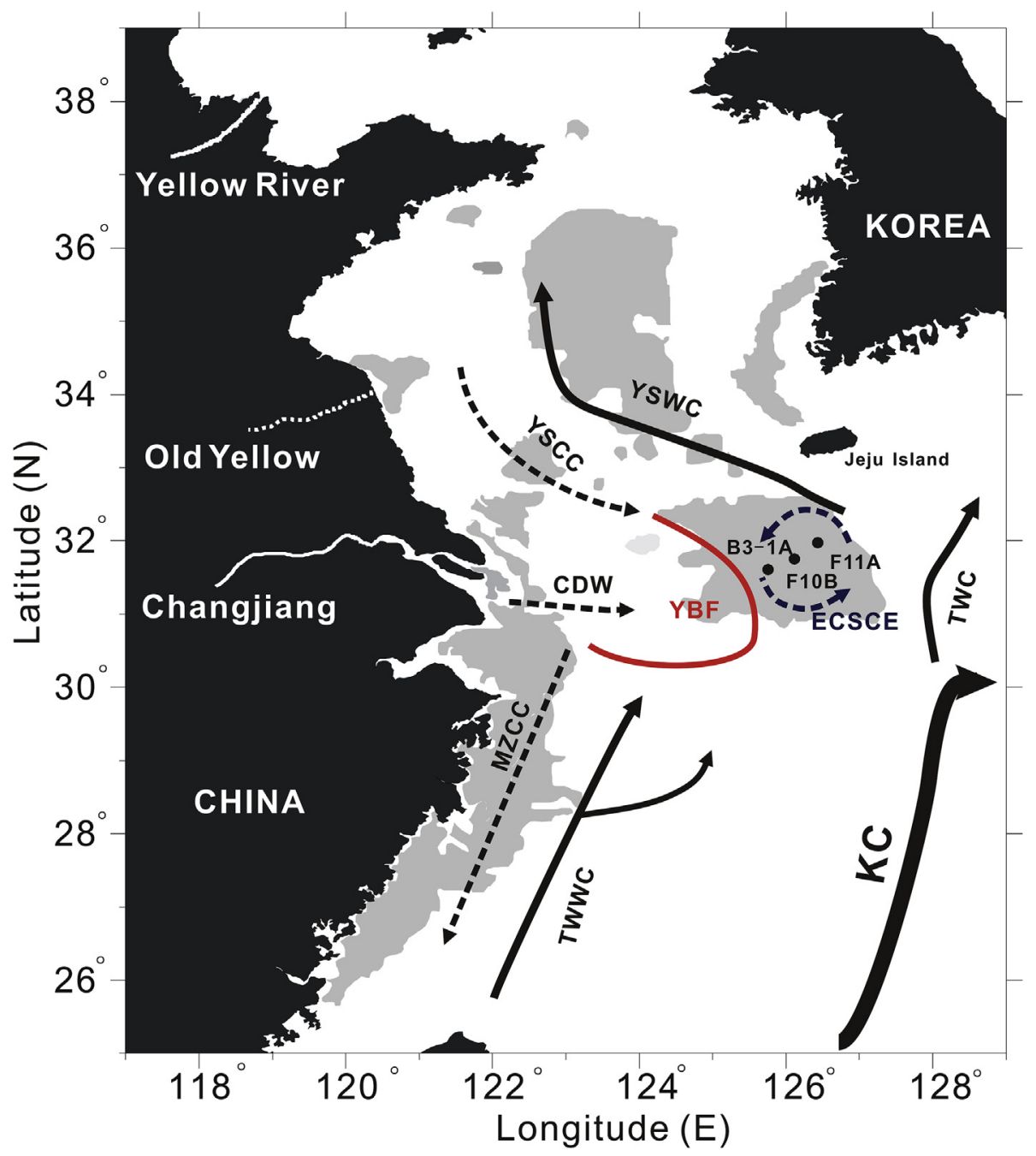

Fig. 1. A schematic map showing B3-1A, F10B and F11A site ( $)$, the distribution of mud sediment areas, and the regional circulation system in the ECS and the YS during winter. Dark grey represents mud areas. KC: Kuroshio Current; YSWC: Yellow Sea Warm Current; TWC: Tsushima Warm Current; TWWC: Taiwan Warm Current; YSCC: Yellow Sea Coastal Current; CDW: Changjiang Diluted Water; MZCC: Minzhe Coastal Current; YBF: Yangtze Bank Front; ECSCE: East China Sea Cold Eddy.

circulation patterns, with strong horizontal and vertical temperature gradients (Chen, 2009; Lie and Cho, 2016). In winter, coastal currents including the Yellow Sea Coastal Current (YSCC) and the Minzhe Coastal Current (MZCC) carry cold and low salinity water southward (Fig. 1). Conversely, the offshore currents including the Yellow Sea Warm Current (YSWC) and the Taiwan Warm Current (TWWC) carry warm and high salinity water northward (Fig. 1). Cold coastal waters and the warm Kuroshio water meet at the shelf of the ECS, contributing to various hydrographic features such as oceanic fronts and cold eddies (Fig. 1). In summer, the circulation system in ECS is relatively weak as the coastal currents are not evident due to the reversed monsoon. In addition, the Changjiang Diluted Water (CDW) flows northeastward which also affects the surface circulation. Temperature is quite uniform in surface waters of the entire ECS shelf, while showing strong stratification in the thermal structure due to higher solar radiation heating of surface waters.

Paleoclimate records from the ECS could provide important evidence to understand the influence of ocean circulation on temperature changes over the Holocene. Previous reconstructions showed that the basic structure of the modern circulation system in the ECS was first established at 6.0-7.0 ka (Li et al., 2009b; Xiang et al., 2008), and probably reached the present level since the late Holocene (Xing et al., 2013; Zhao et al., 2013). However, our knowledge was still very limited on the temporal and spatial temperature patterns in the Holocene, as well as the vertical temperature structure, in response to the evolution of circulation system in the ECS, because existing temperature records were either short time scale or low temporal resolution (Badejo et al., 2014; Li et al., 2009a; Zhao et al., 2014). In addition, most published studies mainly focused on SST variations, but did not consider vertical temperature structure changes. The latter is very important, as the seasonal shift of modern circulation system can result in significant changes in stratification (Chen, 2009). A preliminary study using Holocene temperature records (Xing et al., 2013) observed opposite trends of surface and subsurface temperature changes, suggesting different forcing mechanisms. Therefore, better assessments of the Holocene circulation system changes are important for quantifying and explaining both horizontal and vertical temperature patterns in the ECS.

Surface and subsurface temperature records can be obtained using the $U_{37}^{K^{\prime}}$ and $\mathrm{TEX}_{86}$ indices, respectively. They are widely used temperature proxies and have been applied successfully for Holocene temperature reconstructions in the China marginal seas (Ge et al., 2014; Nan et al., 2017; Wang et al., 2011; Xing et al., 2013). The $U_{37}^{K^{\prime}}$ values in surface sediments of the Yellow Sea (YS) and the ECS display a good linear correlation with the instrumental annual SST, confirming that the $U_{37}^{K^{\prime}}$-derived SST represents annual mean SST (Tao et al., 2012). While the $\mathrm{TEX}_{86}$ values in surface sediments displayed a good linear 
correlation with the instrumental annual subsurface temperature in the YS and ECS (Xing et al., 2015), covering the core sites in our study. Xing et al. (2013) and Yamamoto et al. (2013) also found that the TEX ${ }_{86}$ temperatures were consistently lower than the $U_{37}^{K^{\prime}}$ temperatures in Holocene sediments from the ECS and northern Okinawa Trough, respectively. Here, we report $U_{37}^{K^{\prime}}$ and $\mathrm{TEX}_{86}$ temperature records in three cores (including published records from core F10B) from the ECS shelf to gain new insights into the temporal and spatial patterns of Holocene temperature structure variations. The comparisons of the multi-core reconstructions permit us to integrate the overall temperature trends in response to global climate and regional circulation, and to discuss the mechanisms for the spatial differences of temperature structures.

\section{Study area}

The climate in the ECS is predominantly controlled by the East Asian monsoon system. In winter, the strong northerly winds from the Siberia carry cold and dry air to the region and the river discharge to the ECS is typically low. In summer, southerly winds from the Pacific Ocean bring warm and humid air, resulting in higher precipitation and river discharge to the ECS. The dynamic interactions of shelf water and the $\mathrm{KC}$ water create remarkable hydrographic features in this region. The ECS Cold Eddy is a well-defined counterclockwise cyclonic eddy, located in the southwest of the Jeju Island (Fig. 1). It was first reported by Inoue (1975), and later was confirmed by numerous studies (Hu, 1984; Qu and Hu, 1993). This cyclonic eddy can result in cold water upwelling from deep layers generating a cold area of $100-200 \mathrm{~km}$ in diameter. The cold center of the ECS Cold Eddy does not usually appear at the surface but is evident in the subsurface (below $10 \mathrm{~m}$ ), which could be $5{ }^{\circ} \mathrm{C}$ lower than surrounding areas. The year-round existence of the upwelling also creates high phytoplankton productivity and highly valuable fishing ground in this region. The Yangtze Bank Front (YBF) is a large-scale frontal system located in the edge of the Yangtze Bank along the 50-m isobaths (Fig. 1) (Chen, 2009; Hickox et al., 2000). This front is caused by the interactions of cold coastal waters and the warm KC water and is maintained by tidal rectification (Belkin et al., 2009). Satellite-derived SST images reveal obvious seasonality of the YBF which is enhanced and apparent throughout the winter, while it disappears in summer (Lee et al., 2014). The water masses separated by the YBF have distinct features in temperature, salinity and nutrient (Chen, 2009). The cross-frontal differences of SST in winter can be as large as $3-4{ }^{\circ} \mathrm{C}$ (Hickox et al., 2000). The unique hydrographic feature also leads to the formation of mud area southwest of the Jeju Island. This mud area developed since $7.0 \mathrm{ka}$, with accumulation rates ranging from 0.02 to $0.2 \mathrm{~cm} / \mathrm{yr}$. Sediments were generally considered to be originated from the Changjiang River and the Yellow River (Alexander et al., 1991; Hu et al., 2014; Lee and Chough, 1989; Lim et al., 2006; Milliman et al., 1985a, 1985b; Park and Khim, 1992).

\section{Materials and methods}

Gravity core F11A $\left(126^{\circ} 21^{\prime} \mathrm{E}, 31^{\circ} 53^{\prime} \mathrm{N}\right.$, water depth: $93 \mathrm{~m}$, core length: $206 \mathrm{~cm})$ and B3-1A $\left(125^{\circ} 45^{\prime} \mathrm{E}, 31^{\circ} 37^{\prime} \mathrm{N}\right.$; water depth: $65 \mathrm{~m}$, core length: $289 \mathrm{~cm}$ ) were collected on R/V Dongfanghong2 in 2011. Detailed information of gravity core F10B had been reported (Xing et al., 2013; Yuan et al., 2013). The locations of the three cores were in a west-east section in the mud area to the southwest of the Jeju Island, with B3-1A in the west, F10B in the middle and F11A in the east (Fig. 1; Table 1). All sediment cores were sampled at $1 \mathrm{~cm}$ intervals for temperature proxy analysis.

The sample processing and instrumental analyses for biomarker proxies $\left(U_{37}^{K^{\prime}}\right.$ and $\left.\mathrm{TEX}_{86}\right)$ followed those in the previous studies (Xing et al., 2013; Yuan et al., 2013; Zhao et al., 2013). Briefly, freeze-dried sediments were extracted by $\mathrm{CH}_{2} \mathrm{Cl}_{2} / \mathrm{CH}_{3} \mathrm{OH}(3: 1, \mathrm{v} / \mathrm{v})$. The extracts were hydrolyzed with $6 \% \mathrm{KOH}$ in $\mathrm{CH}_{3} \mathrm{OH}$. The neutral lipids were extracted with hexane and then separated into two fractions using silica
Table 1

Core locations in this study.

\begin{tabular}{llllll}
\hline Core & Longitude (E) & Latitude $(\mathrm{N})$ & Water depth $(\mathrm{m})$ & Length $(\mathrm{cm})$ & Location \\
\hline B3-1A & $125^{\circ} 45^{\prime}$ & $31^{\circ} 37^{\prime}$ & 65 & 289 & west \\
F10B & $126^{\circ} 7^{\prime}$ & $31^{\circ} 45^{\prime}$ & 76 & 141 & middle \\
F11A & $126^{\circ} 21^{\prime}$ & $31^{\circ} 53^{\prime}$ & 93 & 206 & east \\
\hline
\end{tabular}

gel chromatography. The polar lipid fraction (containing alkenones and GDGTs) was eluted with $\mathrm{CH}_{2} \mathrm{Cl}_{2} / \mathrm{CH}_{3} \mathrm{OH}(95: 5$, v/v), and then was divided into two parts. One was derivatized using N, O-bis (trimethylsily)trifluoroacetamide (BSTFA) and the other was filtered by PTFE membrane $(0.45 \mu \mathrm{m})$ before instrumental measurements. Alkenones were determined by GC (Agilent 7890 A) with an FID detector and a HP-1 column $(50 \mathrm{~m} \times 0.32 \mu \mathrm{m} \times 0.17 \mu \mathrm{m})$. GDGTs were determined using HPLC-MS (Agilent 1200/Waters Micromass-Quattro Ultima ${ }^{\mathrm{TM}} \mathrm{Pt}$ ) with an APCI probe and a Prevail Cyano Column $(150 \times 2.1 \mathrm{~mm}, 3 \mu \mathrm{m})$.

$U_{37}^{K^{\prime}}$ values were calculated based on the relative abundance of $C_{37}$ alkenones (Eq. (1)) (Prahl et al., 1988) and were converted into temperature using a local core-top calibration based on data from 30 surface sediments with modern annual surface temperature (Eq. (2)) (Tao et al., 2012).

$U_{37}^{K^{\prime}}=\left(\frac{C_{37: 2}}{C_{37: 2}+C_{37: 3}}\right)$

$U_{37}^{K^{\prime}}=0.059 T-0.350, r^{2}=0.912, n=30$

where $\mathrm{C}_{37: 2}$ and $\mathrm{C}_{37: 3}$ indicated the $\mathrm{C}_{37}$ alkenones with 2 and 3 double bonds, respectively.

$\mathrm{TEX}_{86}{ }^{\mathrm{L}}$ index, a modified version of $\mathrm{TEX}_{86}$, was calculated based on the relative abundance of GDGTs (Eq. (3)) (Kim et al., 2010) and converted into temperature according to a local equation based on data from 22 surface sediments with modern annual bottom temperature (Eq. (4)) (Xing et al., 2015).

$T E X_{86}{ }^{L}=\log \left(\frac{[G D G T 2]}{[G D G T 1]+[G D G T 2]+[G D G T 3]}\right)$

$T E X_{86}^{L}=0.03 B W T-0.94, r^{2}=0.86, n=22$

where L stood for low temperature and the numbers 1-3 indicated the number of cyclopentane rings in GDGTs.

The analytical precision of these methods is ca. $0.3^{\circ} \mathrm{C}$ for $U_{37}^{K^{\prime}}$ and $0.5^{\circ} \mathrm{C}$ for $\mathrm{TEX}_{86} \mathrm{~L} . \Delta \mathrm{T}$ was calculated by $U_{37}^{K^{\prime}}$ and $\mathrm{TEX}_{86}{ }^{\mathrm{L}}$ temperature differences to represent the stratification strength $\left(\Delta \mathrm{T}=U_{37}^{K^{\prime}}\right.$-SST $\mathrm{TEX}_{86}{ }^{\mathrm{L}}$-BWT).

\section{Results}

\subsection{Chronology}

Benthic foraminifers from 6 depths of Core B3-1A and from 5 depths of Core F11A were picked for AMS ${ }^{14} \mathrm{C}$ dating at Peking University following the procedure developed by Liu et al. (2007). All the measured AMS ${ }^{14} \mathrm{C}$ ages were calibrated to calendar ages using the CALIB 6.1.1 program and were corrected for a regional marine reservoir age $(\Delta$ $\mathrm{R}=-128 \pm 35 \mathrm{yr}$ ) (Stuiver et al., 1998). The age model of Core F10B was previously published (Xing et al., 2013; Yuan et al., 2013), which consisted of AMS ${ }^{14} \mathrm{C}$ dated benthic foraminifers from 5 depths and was calibrated to calendar ages using the same data analysis.

The ${ }^{14} \mathrm{C}$-dated core depths for $\mathrm{B} 3-1 \mathrm{~A}$ covered a time span of the last $9.0 \mathrm{ka}$ (Fig. 2A). Linear interpolation between radiocarbon dates yielded sedimentation rates between 10.2 and $142.0 \mathrm{~cm} / \mathrm{ka}$. The ${ }^{14} \mathrm{C}$ dated core depths for F10B ranged from 1.4 to $14 \mathrm{ka}$ and generated sedimentation rates between 6.2 and $49.7 \mathrm{~cm} / \mathrm{ka}$ (Fig. 2B). The dated core interval for F11A spanned the mid-late Holocene $(<4.5 \mathrm{ka})$ with 

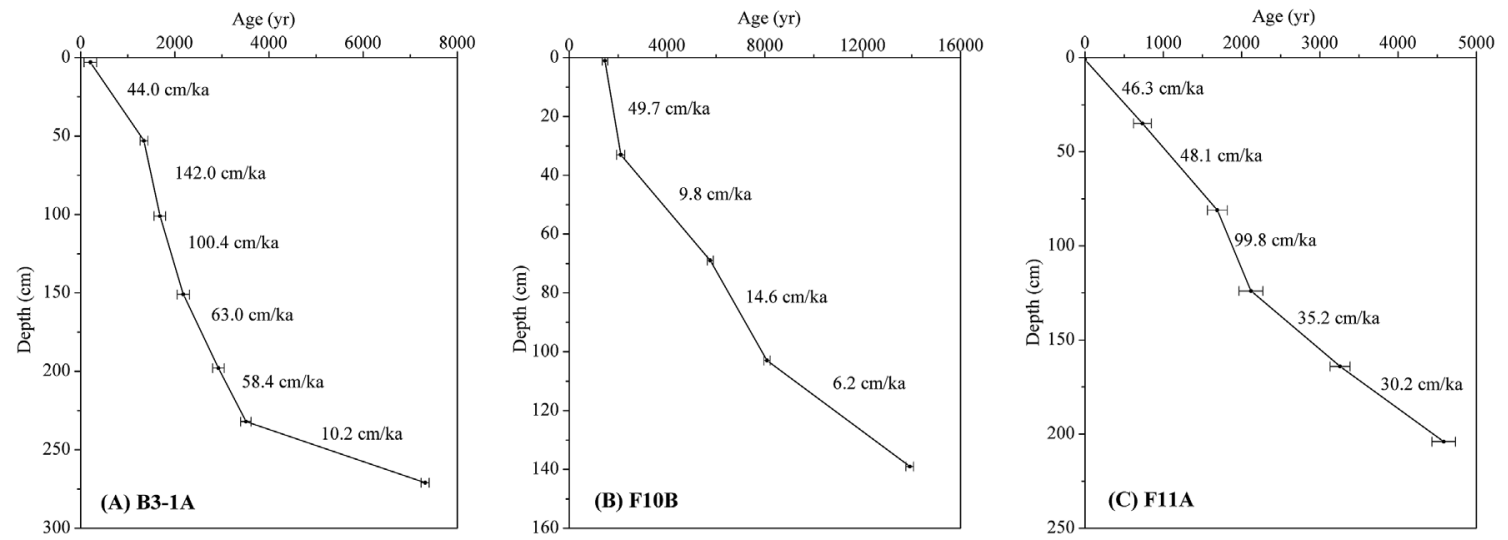

Fig. 2. Age-depth plots for Cores B3-1A (A), F10B (B) and F11A (C). Sedimentation rates are calculated using the calibrated ages (yr) of the dated horizons. Error bar denotes the two sigma age range.

sedimentation rates between 35.2 and $99.8 \mathrm{~cm} / \mathrm{ka}$ (Fig. 2C). The average sedimentation rate of F11A $(45.8 \mathrm{~cm} / \mathrm{ka})$ was higher than that of B3-1A $(32.1 \mathrm{~cm} / \mathrm{ka})$ and F10B $(10.1 \mathrm{~cm} / \mathrm{ka})$. The $2 \sigma$ error bars for ${ }^{14} \mathrm{C}$ calendar ages are typically smaller than $300 \mathrm{yr}$ (Fig. 2).

\subsection{Temperature variations in B3-1A (west site)}

$U_{37}^{K^{\prime}}$ temperature ranged from $17.9{ }^{\circ} \mathrm{C}$ to $20.9{ }^{\circ} \mathrm{C}$ and displayed an overall decreasing trend (Fig. 3A; Table 2). During 9.0 to $6.0 \mathrm{ka}, U_{37}^{K^{\prime}}$ temperature was relatively high with an average of $20.2^{\circ} \mathrm{C}$. There were several missing data due to the low contents of $\mathrm{C}_{37}$ alkenones. During the period of 6.0 to $1.0 \mathrm{ka}, U_{37}^{K^{\prime}}$ temperature showed a slight decrease with an average of $19.5^{\circ} \mathrm{C}$. The period of last $1.0 \mathrm{ka}$ was characterized by a rapid decrease of $U_{37}^{K^{\prime}}$ temperature with an average of $18.8^{\circ} \mathrm{C}$. $\mathrm{TEX}_{86}{ }^{\mathrm{L}}$ temperature ranged from $14.2^{\circ} \mathrm{C}$ to $17.3^{\circ} \mathrm{C}$ with an overall increasing trend (Fig. 3B). The average $\mathrm{TEX}_{86}{ }^{\mathrm{L}}$ temperature during the three periods was $15.1{ }^{\circ} \mathrm{C}, 15.5^{\circ} \mathrm{C}$ and $15.7^{\circ} \mathrm{C}$, respectively (Table 2). $\Delta \mathrm{T}$ ranged from $1.2{ }^{\circ} \mathrm{C}$ to $5.9^{\circ} \mathrm{C}$ with an overall decreasing trend (Fig. 3C). The average value of $\Delta \mathrm{T}$ during the three periods was $5.1^{\circ} \mathrm{C}$, $4.0{ }^{\circ} \mathrm{C}$ and $3.1{ }^{\circ} \mathrm{C}$, respectively (Table 2 ).

\subsection{Temperature variations in $\mathrm{F} 10 \mathrm{~B}$ (middle site)}

The $U_{37}^{K^{\prime}}$ and $\mathrm{TEX}_{86}$ temperatures for $\mathrm{F} 10 \mathrm{~B}$ reported previously by Xing et al. (2013) were recalculated using the local calibration equations and are now described for a comparison in this study. $U_{37}^{K^{\prime}}$ temperature ranged from $17.6{ }^{\circ} \mathrm{C}$ to $20.6{ }^{\circ} \mathrm{C}$, and displayed an overall decreasing trend (Fig. 3D; Table 2). During 10.0 to $6.0 \mathrm{ka}, U_{37}^{K^{\prime}}$ temperature was relatively high with an average of $20.1^{\circ} \mathrm{C}$. During the period of 6.0 to $2.0 \mathrm{ka}, U_{37}^{K^{\prime}}$ temperature showed a slight decrease with an average of $19.4^{\circ} \mathrm{C}$. During the period of 2.0 to $1.4 \mathrm{ka}, U_{37}^{K^{\prime}}$ temperature displayed a rapid decrease with an average of $18.2^{\circ} \mathrm{C}$. $\mathrm{TEX}_{86}{ }^{\mathrm{L}}$ temperature ranged from $12.8^{\circ} \mathrm{C}$ to $15.8^{\circ} \mathrm{C}$ with a slight increasing trend (Fig. 3E). The average $\mathrm{TEX}_{86}{ }^{\mathrm{L}}$ temperature during the three periods was $14.6{ }^{\circ} \mathrm{C}, 14.7^{\circ} \mathrm{C}$ and $14.7^{\circ} \mathrm{C}$, respectively (Table 2). $\Delta \mathrm{T}$ ranged from $2.7^{\circ} \mathrm{C}$ to $6.9^{\circ} \mathrm{C}$ with an overall decreasing trend (Fig. 3F). The average value of $\Delta \mathrm{T}$ during the three periods was $5.4^{\circ} \mathrm{C}, 4.7^{\circ} \mathrm{C}$ and $3.5^{\circ} \mathrm{C}$, respectively (Table 2 ).

\subsection{Temperature variations in $F 11 A$ (east site)}

The records for F11A were higher resolution and over a shorter time
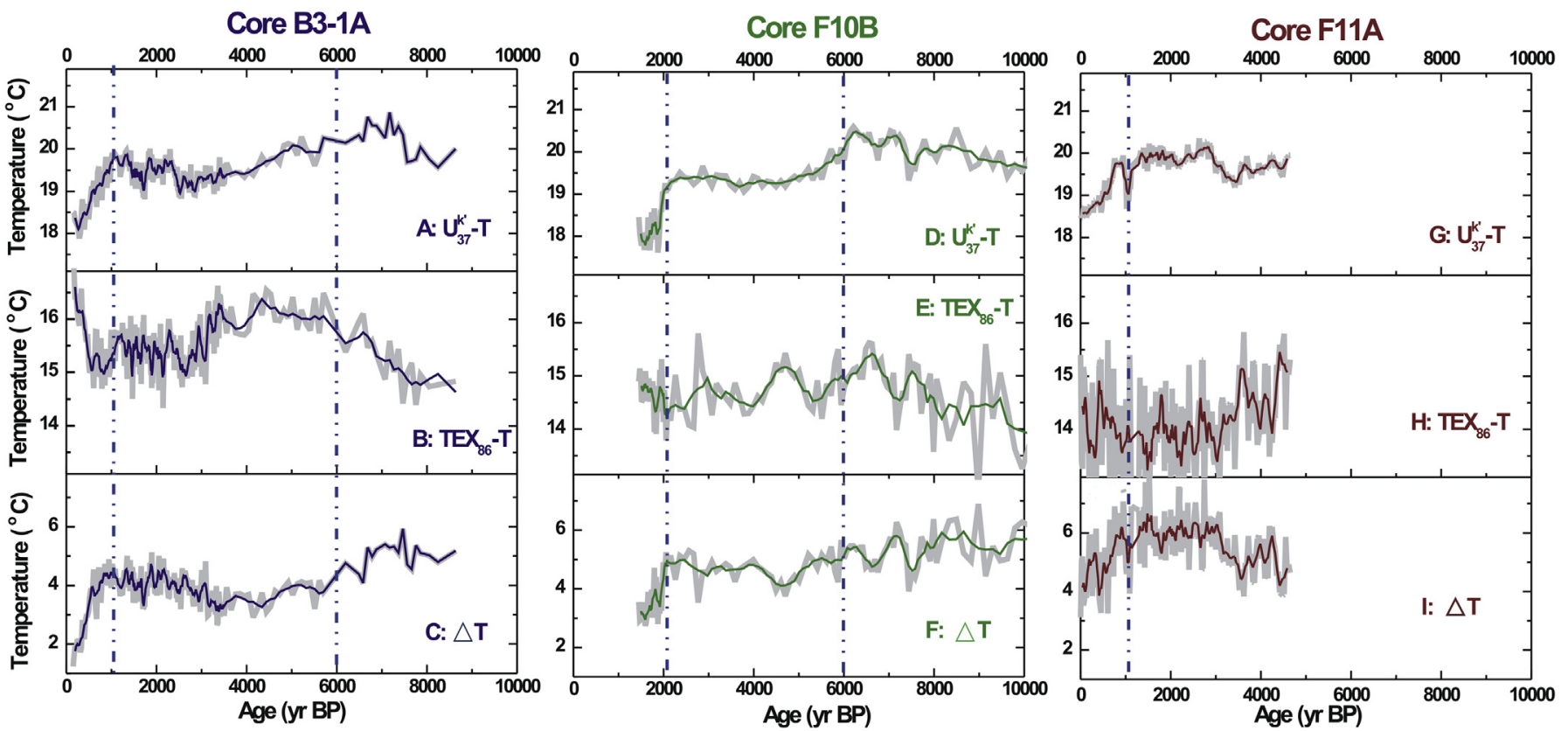

Fig. 3. Holocene temperature records from Cores B3-1A (left panel), F10B (middle panel) and F11A (right panel) (averaged and smoothed). (A, D, G) $U_{37}^{K^{\prime}}$ temperature; (B, E, H) $\mathrm{TEX}_{86}{ }^{\mathrm{L}}$ temperature; (C, F, I) $\Delta \mathrm{T}\left(U_{37}^{K^{\prime}}\right.$ and $\mathrm{TEX}_{86}{ }^{\mathrm{L}}$ temperature difference). The dotted vertical lines indicate temperature shifts. 
Table 2

Temperature averages of each interval in Cores B3-1A, F10B and F11A.

\begin{tabular}{|c|c|c|c|c|c|c|c|c|c|c|}
\hline \multicolumn{2}{|c|}{ Time interval } & \multicolumn{3}{|c|}{$0-1.0 / 2.0 \mathrm{ka}$} & \multicolumn{3}{|c|}{$1.0 / 2.0-6.0 \mathrm{ka}$} & \multicolumn{3}{|c|}{$6.0-10.0 \mathrm{ka}$} \\
\hline Location & Core & $\mathrm{U}_{37}^{\mathrm{K}^{\prime}}$ & $\operatorname{TEX}_{86}{ }^{\mathrm{L}}$ & $\Delta \mathrm{T}$ & $\mathrm{U}_{37}^{\mathrm{K}^{\prime}}$ & $\operatorname{TEX}_{86}{ }^{\mathrm{L}}$ & $\Delta \mathrm{T}$ & $\mathrm{U}_{37}^{\mathrm{K}^{\prime}}$ & $\mathrm{TEX}_{86}{ }^{\mathrm{L}}$ & $\Delta \mathrm{T}$ \\
\hline west & B3-1A & 18.8 & 15.7 & 3.1 & 19.5 & 15.5 & 4.0 & 20.2 & 15.1 & 5.1 \\
\hline middle & F10B & 18.2 & 14.7 & 3.5 & 19.4 & 14.7 & 4.7 & 20.1 & 14.6 & 5.4 \\
\hline east & F11A & 19.0 & 14.1 & 5.0 & 19.8 & 14.1 & 5.7 & & & \\
\hline
\end{tabular}

span of the last $4.5 \mathrm{ka} . U_{37}^{K^{\prime}}$ temperature ranged from $18.5^{\circ} \mathrm{C}$ to $20.4^{\circ} \mathrm{C}$, and displayed an overall decreasing trend (Fig. 3G; Table 2). During 4.5 to $1.0 \mathrm{ka}, U_{37}^{K^{\prime}}$ temperature was relatively high with an average of $19.8^{\circ} \mathrm{C}$. During the period of $1.0 \mathrm{ka}$ to the present, $U_{37}^{K^{\prime}}$ temperature displayed a rapid decrease with an average of $19.0^{\circ} \mathrm{C}$. $\operatorname{TEX}_{86}{ }^{\mathrm{L}}$ temperature varied significantly from $11.7^{\circ} \mathrm{C}$ to $15.8^{\circ} \mathrm{C}$ (Fig. $3 \mathrm{H}$ ). The average value of $\mathrm{TEX}_{86}{ }^{\mathrm{L}}$ temperature during the two periods was the same $\left(14.1^{\circ} \mathrm{C}\right.$; Table 2$) . \Delta \mathrm{T}$ ranged from $3.1^{\circ} \mathrm{C}$ to $8.0^{\circ} \mathrm{C}$ and the average value of $\Delta \mathrm{T}$ during the two periods was $5.7^{\circ} \mathrm{C}$ and $5.0^{\circ} \mathrm{C}$, respectively (Fig. 3I; Table 2).

\section{Discussions}

The $U_{37}^{K^{\prime}}$ index is based on the unsaturation extent of long-chain alkenones with 37 carbon atoms found in marine haptophyte algae such as Emiliani huxleyi and Gephyrocapsa oceanica, which have been universally used for SST calculation globally (e.g. Müller et al., 1998; Zhao et al., 2006; Max et al., 2012). The TEX ${ }_{86}$ index is based on the relative distribution of marine archaea isoprenoid glycerol dialkyl glycerol tetraethers (GDGTs), most likely reflecting subsurface rather than surface temperatures in many different marine environments, such as in the Santa Barbara Basin, the eastern tropical North Atlantic, the Gulf of California, and the Southern China Sea (Huguet et al., 2007; Lopes dos Santos et al., 2010; McClymont et al., 2012; Li et al., 2013). However, other studies argued that the $\mathrm{TEX}_{86}$ index may be constrained by several non-temperature factors such as iGDGTs transported from terrestrial soils (Hopmans et al., 2004), incorporation of methanotrophic archaea (Zhang et al., 2011), growth phase and species variability (Elling et al., 2014) and dissolved $\mathrm{O}_{2}$ (Qin et al., 2015). Nakanishi et al. (2012a) reported high contents of isoprenoid GDGTs in suspended particles from the subsurface water in the ECS, suggesting that TEX index is a reliable proxy for subsurface temperature reconstructions in our study area. Considering the shallow depth in the YS and ECS, TEX 86 temperature is also a proxy for bottom water temperature (BWT). Thus, the temperature differences $(\Delta \mathrm{T})$ between these two proxies yield a quantitative reconstruction of stratification, which has been applied successfully in the Okinawa Trough (OT) and the South China Sea (Dong et al., 2015; Li et al., 2013; Yamamoto et al., 2013).

\subsection{Temporal temperature pattern during the Holocene}

The variation trends of $U_{37}^{K^{\prime}}$ SST, $\mathrm{TEX}_{86}{ }^{\mathrm{L}}$ BWT and stratification proxy $(\Delta \mathrm{T})$ in the three cores were generally consistent, respectively (Fig. 3). All SST records were marked by a cooling of ca. $2-3{ }^{\circ} \mathrm{C}$, while the BWT records showed a slight warming, although some decreases were embedded in the middle Holocene. Accordingly, the stratification proxy all exhibited a generally decreasing trend of ca. $4-5^{\circ} \mathrm{C}$. We thereby integrated these records to derive temperature stacks in the ECS. The temperature stacks were generated by taking average means of the three records after the interpolation analyses of chronological data, which could retain their common temporal features but suppress spatial differences in each core.

Previously published data in the study region including temperature (Xing et al., 2013), grain size (Hu et al., 2014), phytoplankton and terrestrial biomarkers (Yuan et al., 2013) have broadly identified three intervals of environmental changes which were the early, middle and late Holocene, but the shift timing for the three intervals varied quite a lot. Our multi-core reconstructions in this study allowed us to better constrain the timing of temperature changes. The reconstructed temperatures broadly displayed a three-interval pattern with distinct shifts at ca. $6.0 \mathrm{ka}$ and 1.0/2.0 ka, each having a very different temperature average (Table 2). The late Holocene temperature change occurred at 2.0 ka for the Core F10B while at 1.0 ka for Core B3-1A and F11A, probably caused by age control, bioturbation, or oceanic forcing. We focus on the oceanic forcing which might drive the temperature change in this study. In the following section, we compare the stacked temperature record with other climate records and discuss the possible climate forcing for each interval.

\subsubsection{Strong stratification during the early Holocene (10.0-6.0 ka)}

As a result of the retreat of continental ice sheet, global and the ECS sea level rose from the glacial to the early Holocene and reached the present position at about $7.0 \mathrm{ka}$ (Fig. 4H; Liu et al., 2004). Low contents of $\mathrm{C}_{37}$ alkenones and high contents of long chain $n$-alkanols (Yuan et al., 2013) suggested a shallower sea environment with enhanced terrestrial influence in our study area. However, the influence from the terrestrial material input on the TEX 86 index is minor on the basis of the low BIT values in all three cores $(<0.3$, unpublished data). The shallow sea environment for most of the ECS would also constrain the geographical space and pathways for the intrusion of the KC to the shelf of ECS (Li et al., 2009b). Thus, the influence of the KC to our study area must be limited during the early Holocene due to lower sea level. Our $U_{37}^{K^{\prime}}$ records indicated that SSTs were considerably higher during the early Holocene than other periods (Fig. 4A). This coincides with the high values of global annual temperature (Fig. 4D) and summer insolation (Fig. 4G). The global high temperature during the early Holocene has been attributed to summer insolation maximum (Renssen et al., 2009, 2012). The similarity between our SST records (Fig. 4A) and global temperature anomalies (Fig. 4D) in the early Holocene suggests the summer insolation forcing as a major factor controlling the SST in the ECS, most likely through surface heating. The timing is also broadly in agreement with continental climate records from China which showed similar warm and wet period from 9.0 to $3.0 \mathrm{ka}$ (Fig. 4F) (Liu et al., 2007; Shi et al., 1992; Zhao et al., 2011). This correlation suggests that early Holocene global climate had similar impact on both terrestrial and marine temperatures in East Asia.

In the study area, the modern BWT shows weak seasonality and is primarily determined by the winter temperature (Li and Yuan, 1992), because the sharp thermocline in the summer can prevent heat transfer from the surrounding area and keep the BWT similar to that of the previous winter. During the early Holocene, the $\mathrm{TEX}_{86}{ }^{\mathrm{L}}$ temperature revealed lower BWT than any time covered by the records (Fig. 4B). This is likely caused by a low winter temperature during the early Holocene which was related to the strong EAWM (East Asian Winter Monsoon) and limited influence from the KC. Although the strength of EAWM in the Holocene was still a controversial issue due to the limited reliable proxies, most published EAWM records displayed a strong EAWM during the early Holocene (Fig. 4E) (Hu et al., 2012; Huang et al., 2011; Wang et al., 2012). Thus, the intense winter monsoon could directly cool temperature though surface heat fluxes and lead to the low 


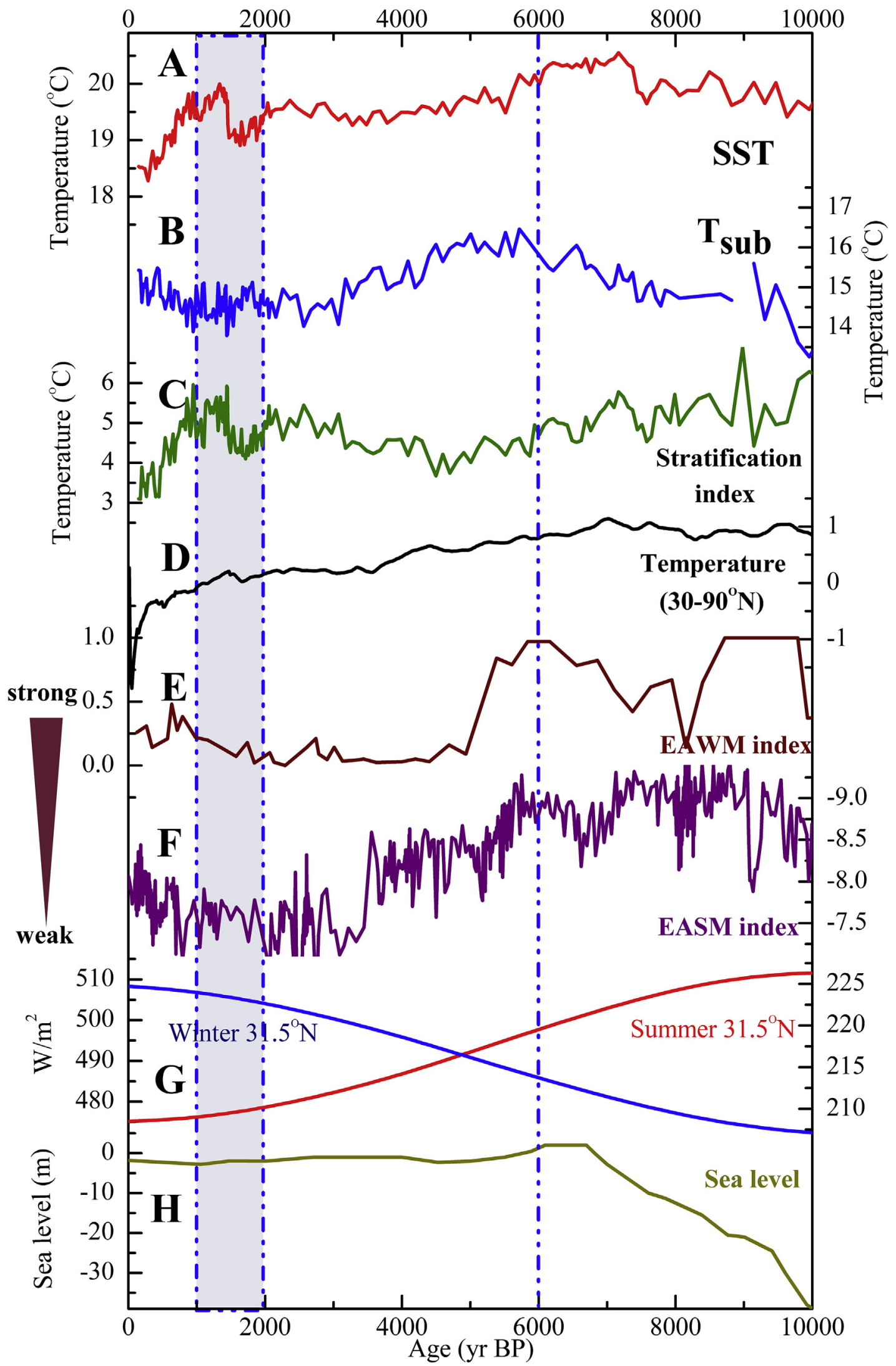

Fig. 4. Stacked surface sea temperature (A), subsurface sea temperature (B) and stratification records (C, temperature differences) in the ECS from this study. Global temperature anomalies (stack $30-90^{\circ} \mathrm{N}$ ) for the Holocene from 73 globally distributed records (Marcott et al., 2013) (D). Diatom assemblage records from Huguang Maar Lake, a proxy for the EAWM intensity (Wang et al., 2012) (E). Stalagmite $\delta^{18}$ O records from Dongge cave (Dykoski et al., 2005), a proxy record of the precipitation and EASM (East Asian Summer Monsoon) intensity in southern China (F). July (red) and December (blue) insolation at $31.5^{\circ} \mathrm{N}\left(\mathrm{W} / \mathrm{m}^{2}\right)(\mathrm{Laskar}$ et al., 2004) (G). Sea level record in the East China Sea (Liu et al., 2004) (H). (For interpretation of the references to colour in this figure legend, the reader is referred to the Web version of this article.) 
winter temperature and overall low BWT during the early Holocene. Many pieces of evidence in the OT pointed to an enhanced KC during the early Holocene (Li et al., 2009b; Xu and Oda, 1999), but the low salinity environment recorded in the YS and ECS suggested that the intrusion of the KC to the shelf of the ECS was still very limited during this period (Xiang et al., 2008). The limited transport of warm water from the KC could also contribute to the lower BWT in the study area during the early Holocene. The high SST coupled with low BWT resulted in strong stratification in the shelf of ECS during the early Holocene, which also likely reflected the contrast between warmer summer and cold winter conditions.

\subsubsection{Weaker stratification during 6.0 to $1.0 / 2.0 \mathrm{ka}$}

At the onset of the middle Holocene about $6.0 \mathrm{ka}$, the study area was characterized by cooler SST, warmer BWT and hence weaker stratification (Fig. 4A-C). This condition persisted to $1.0 \mathrm{ka}$ at core sites B3-1A and F11A and to $2.0 \mathrm{ka}$ at core site F10B. The SST decrease broadly followed global temperature changes during this time interval, suggesting possible influence from decreasing summer insolation. However, a more important driver could be the circulation system, which was distinctly different from that during the early Holocene. Foraminiferal $\delta^{18} \mathrm{O}$ and $\delta^{13} \mathrm{C}$ records revealed that the KC started to influence the YS and ECS since 6.0-7.0 ka (Kim and Kucera, 2000; Li et al., 2009b; Xiang et al., 2008). High marine productivity in the YS and ECS also pointed towards elevated nutrient condition since $6.0 \mathrm{ka}$ possibly related to a newly established circulation system (Xing et al., 2012; Yuan et al., 2013). The intrusion of the KC provided an important heat source to the ECS. However, the strength of the KC has shown a remarkable weak period during 2.7-4.6 ka, known as the Pulleniatina minimum event (Jian et al., 2000). Temperature records from the Okinawa Trough based on the $U_{37}^{K^{\prime}}$ (Nakanishi et al., 2012b), TEX ${ }_{86}$ (Yamamoto et al., 2013) and foraminiferal $\mathrm{Mg} / \mathrm{Ca}$ ratio (Lin et al., 2006) all suggested small changes during this period. Thus, the direct influence of $\mathrm{KC}$ temperature changes to our sites during the middle Holocene could be limited. However, the entrance and strength changes of the KC into the YS and ECS could be important, with the accompanying hydrographic changes. As regional components of the circulation system, the YSCC and ECS cold eddy can be enhanced due to the influence of the KC. Grain size data in the region have revealed significant increase in fine-grained fluxes since $6.8 \mathrm{ka}$, which can be due to the enhanced YSCC or the formation of cold eddy which trapped more sediments (Hu et al., 2014). Therefore, we attributed the decreased SST to the enhanced YSCC and formation of cold eddy which brought more cold water to the surface of our sites. In addition, the initiation of cold eddy during this interval might have also caused weaker stratification through enhanced upwelling.

\subsubsection{Much weaker stratification since $1.0 / 2.0 \mathrm{ka}$}

The global climate system during the mid-late Holocene did not change dramatically after the sea level reached the present position at ca. 7 ka (Wanner et al., 2008, 2011). However, our records revealed significant temperature structure changes at 1.0 ka of cores B3-1A and F11A and at $2.0 \mathrm{ka}$ of core F10B during the late Holocene with rapidly decreased SSTs and increased BWTs, resulting in much weaker stratification (Fig. 4A-C). Compared to the average temperature during the prior interval in core B3-1A, the SST decreased $0.7^{\circ} \mathrm{C}$, while BWT increased $0.2{ }^{\circ} \mathrm{C}$, thus the stratification decreased $0.9^{\circ} \mathrm{C}$ (Table 2). The decreased SST during this interval is consistent with global climate cooling during the Holocene. However, these more significant temperature changes suggested additional regional mechanism in addition to insolation forcing during the early-mid Holocene. One possible process is the strengthening of the cold eddy which can generate strong upwelling and well-mixed water column, hence the weaker stratification. Evidence from China marginal seas has shown an intensified circulation system during the late Holocene. For example, the SST record in the central YS suggested enhanced YSWC since 2.3 ka (Wang et al.,
2011). Biomarker records in the YS also revealed a significant increase in phytoplankton productivity and haptophyte contribution since 3.0 $\mathrm{ka}$, which can be linked to the intensified circulation system (Zhao et al., 2013). The circulation system in the ECS has been considered as the main dynamic factor for the ECS cold eddy (Hu, 1984; Qu and Hu, 1993). With the intensified interaction of the YSWC and YSCC, the ECS cold eddy could also be strengthened during the late Holocene, and thus caused the large sea surface cooling and much weaker stratification. This mechanism is in agreement with modern observations that the ECS cold eddy was strengthened when YSWC was strong (Chen et al., 2004; Hao et al., 2012).

Previous studies have shown that the circulation system in the ECS depended largely on the variability of EAWM, since a strong EAWM could enhance the winter wind-driven coastal current and the compensating warm current (the YSWC), triggering a strong circulation system (Song et al., 2009; Yuan and Hsueh, 2010). However, most Holocene EAWM records showed an overall decreasing trend with only a slightly increase during the late Holocene (Fig. 4E) (Hu et al., 2012; Huang et al., 2011; Wang et al., 2012). Therefore, there might be other climate forcing mechanism on these rapid temperature changes. The ENSO has been proposed as an important factor for circulation system and the ECS cold eddy in modern ECS (Chen et al., 2004; Hao et al., 2012). The warm phase of ENSO could result in strong KC and anomalous cyclonic atmospheric circulation which intensified the ECS cold eddy. For example, when the mean-state of ENSO changed to an El Niño like pattern since 1976 (Power and Smith, 2007), the intensity of the ECS cold eddy increased significantly (Hao et al., 2012). Strong ECS cold eddy has been also clearly observed in most El Niño years since 1960s (Chen et al., 2004). During the late Holocene, the southward migration of the ITCZ has favored a regime of stronger ENSO cycles with increased El Niño events especially since 2.0 ka (Koutavas et al., 2006). Proxy reconstructions of the KC showed increased intensity after the Pulleniatina minimum event (Jian et al., 2000). Our temperature records are therefore in agreement with the reconstructed ENSO and KC, lending credence to the hypothesis that the increased El Niño events could result in a stronger KC, which lead to a stronger ECS cold eddy during the late Holocene.

\subsection{Spatial temperature variations among the three cores}

The most striking difference of the temperature records among the three cores was the significant asynchronous changes during the late Holocene. The remarkable SST decrease and BWT increase occurred at 2.0 ka for Core F10B at the middle position, while they occurred at 1.0 ka for Core B3-1A in the west and F11A in the east. The spatial variation of SST between the three cores might be caused by different factors, including age dating, proxy uncertainties, depositional processes and regional oceanographic/climatic changes. One potential bias of the chronology could be introduced from the linear interpolation, which was especially critical for sediment cores with low-resolution age controls. However, there are reasonable age controls in the three cores during the Late Holocene (Table 3). The sedimentation rate in Core F10B (with earlier temperature shifts at $2.0 \mathrm{ka}$ ) was lower than Core B31A and Core F11A (Fig. 2), implying that it may be more susceptible to bioturbation or lateral transport effects. However, if bioturbation or lateral transport occurred, it is expected to influence both the foraminifera dating and our temperatures records. Thus, we suggest that this spatial heterogeneity of temperature changes was more likely caused by regional processes rather than age uncertainties and sedimentation process.

As the three cores were located within a very small region in the ECS $\left(125.8-126.4^{\circ} \mathrm{E}, 31.6-31.8^{\circ} \mathrm{N}\right)$, global temperature changes should have similar effects on the three temperature records when discussing the spatial temperature differences. Thus, the spatial temperature patterns in our study area might be largely controlled by the regional factors, such as the variability of both the YSWC and cold eddy. In 
Table 3

Foraminifera ${ }^{14} \mathrm{C}$ data of Core B3-1A, F10B and F11A. All the measured $\mathrm{AMS}^{14} \mathrm{C}$ ages were calibrated to calendar ages using the CALIB6.1.1 program and were corrected for a regional marine reservoir age $(\Delta \mathrm{R}=-128 \pm 35 \mathrm{yr})$.

\begin{tabular}{lllll}
\hline Core & Depth $(\mathrm{cm})$ & ${ }^{14} \mathrm{C}$ age $(\mathrm{yr})$ & SD $( \pm \mathrm{yr})$ & Calendar age $(\mathrm{yr} \mathrm{BP})$ \\
\hline B3-1A & 3 & 450 & 25 & 208 \\
& 53 & 1675 & 30 & 1345 \\
& 101 & 1975 & 25 & 1683 \\
& 151 & 2380 & 25 & 2181 \\
& 198 & 3015 & 20 & 2927 \\
& 232 & 3485 & 20 & 3509 \\
F10B & 270 & 6660 & 25 & 7318 \\
& 1 & 1790 & 25 & 1462 \\
& 33 & 2330 & 25 & 2106 \\
& 69 & 5265 & 30 & 5768 \\
& 103 & 7505 & 35 & 8090 \\
F11A & 139 & 12355 & 40 & 13924 \\
& 35 & 1065 & 25 & 734 \\
& 81 & 1980 & 25 & 1690 \\
& 124 & 2340 & 25 & 2121 \\
& 164 & 3255 & 25 & 3258 \\
& 204 & 4290 & 30 & 4584 \\
\hline
\end{tabular}

general, the SST in F11 (east) was higher than that in F10 (middle) and B3-1 (west) (Fig. 3; Table 2), because the core site of F11 is much closer to the YSWC (Fig. 1). In addition, the west-east temperature gradients along the 50-100 $\mathrm{m}$ isobaths generated by the YBF (Fig. 1; Hwang et al., 2014) might also contribute to the higher SST in the eastern core. Interestingly, the SST in the middle core F10 was lower than that in the western core B3-1 (Fig. 3; Table 2), although it was closer to the YSWC (Fig. 1), compensated by the influence of the ESC cold eddy (Chen et al., 2004). In summer, the ECS cold eddy induces a cold center at $31.8-32.2^{\circ} \mathrm{N}, 125.8^{\circ} \mathrm{E}$, with significantly lower temperature than the surrounding area (Gang et al., 2010). The area affected by the ECS cold eddy extends about $100-200 \mathrm{~km}$ covering all the three sites, with the middle site $\left(\mathrm{F} 10,31.8^{\circ} \mathrm{N}, 126.1^{\circ} \mathrm{E}\right)$ close to the cold center $\left(31.8-32.2^{\circ} \mathrm{N}, 125.8^{\circ} \mathrm{E}\right)$ and the west and east site near the edge. The slightly lower SST averages in our middle core (F10B) is most likely related to the center of ECS cold eddy (Fig. 5; Table 2). At $2.0 \mathrm{ka}$, the cold center was first enhanced around the middle site. As the circulation system strengthened, its influence area expanded and started to affect the west and east sites at $1.0 \mathrm{ka}$. Therefore, we infer that the observed spatial temperature variability was caused by the combined effect of the YSWC, YBF and cold eddy.

\subsection{Summary of Holocene surface circulation evolution and implications for future regional environmental change}

Based on the three Holocene temperature records in the shelf of ECS, we try to synthesize these results into a coherent description of regional environment evolution. As discussed above, particular attention was given to two significant shifts at ca. $6.0 \mathrm{ka}$ and 1.0/2.0 ka during the Holocene. In the early Holocene (Fig. 5A), with no or weak modern-type circulation system, the influences of the KC and coastal currents were limited. The shelf of the ECS showed higher SST and strong stratification $\left(5.1^{\circ} \mathrm{C}\right)$. During the interval of $6.0-1.0 / 2.0 \mathrm{ka}$ (Fig. 5B), both the YSCC and the YSWC started to influence the shelf of the ECS leading to the formation of the ECS cold eddy (Li et al., 2009b; Xiang et al., 2008), but the circulation system was still weak. The temperatures in the shelf of ECS revealed decreased SST and weaker stratification $\left(4.0^{\circ} \mathrm{C}\right.$ ). Since $1.0 / 2.0 \mathrm{ka}$ in the late Holocene (Fig. $5 \mathrm{C}$ ), the circulation system was strengthened with strong YSCC and YSWC, generating intensified cold eddy. As a result, the shelf of the ECS showed abruptly decreased SST and decreased BWT with much weaker stratification $\left(3.1^{\circ} \mathrm{C}\right)$. This temperature structure change showed significant spatial asynchrony, caused by the expansion of the cold eddy affected area.

Thus, these temperature structure changes are controlled by the gradual establishment and strengthening of the circulation system. Circulation system was not established or weak in the early Holocene, initiated in the middle Holocene and enhanced in the late Holocene. Based on our records, the strength of stratification has decreased from $5.1{ }^{\circ} \mathrm{C}$ to $3.1{ }^{\circ} \mathrm{C}$ throughout the Holocene. Thus, our study provides an empirical relationship between regional circulation system and thermocline structure with important implication for future environmental changes. With increasing greenhouse gas emissions, it has been proposed that the global temperature will exceed the full Holocene range by 2100 (Marcott et al., 2013), and a model simulation also suggested warmer temperature with stronger stratification in the future for the Bohai Sea, YS and ECS (Mao et al., 2017). Thus, the future ECS would likely have a weak circulation system similar to that of the middle Holocene period in the future.

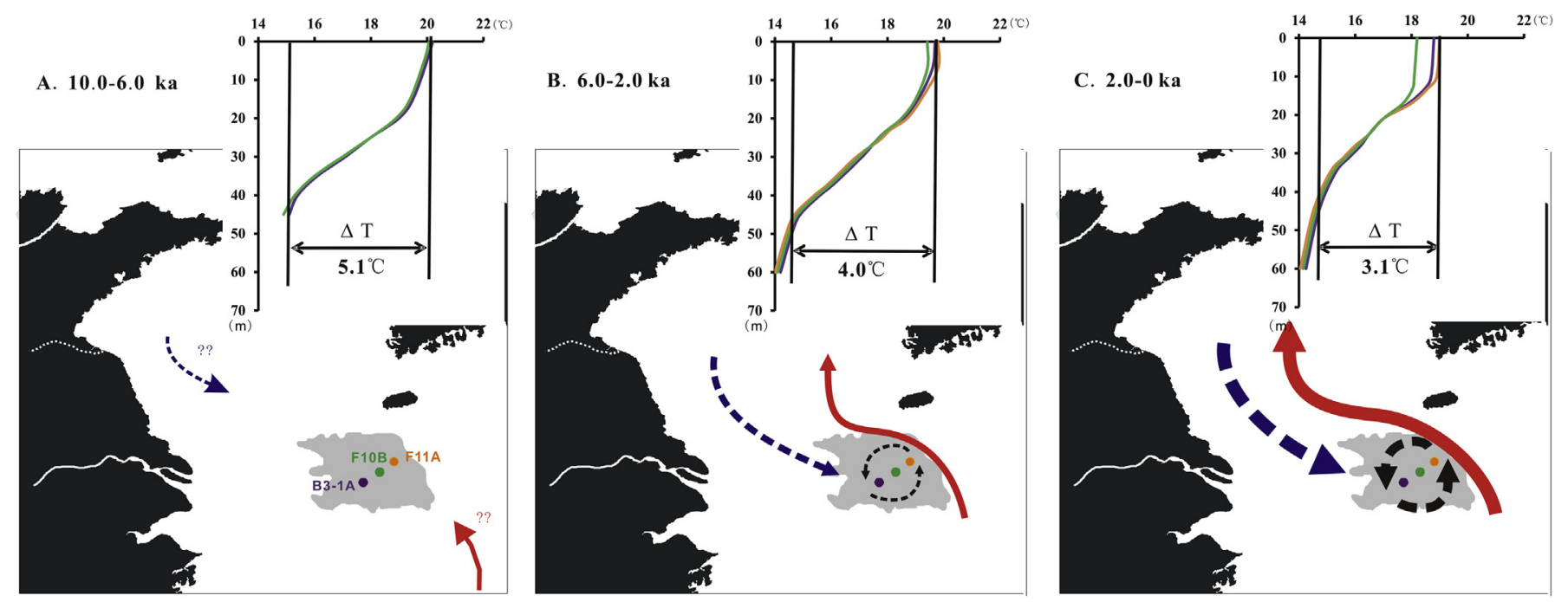

Fig. 5. Schematic diagrams for Holocene temperature structure changes and circulation system evolution in the shelf of East China Sea. The conditions of regional circulation system are shown in black (ECS cold eddy), red (YSWC) and blue (YSCC) arrows. The vertical thermal structures in each stage are plotted according to the average temperature records (B3-1A: purple; F10B: green; F11A: orange) and shown in the up right corner. A. 10.0-6.0 ka; B. 6.0-2.0 ka; C. 2.0-0 ka. (For interpretation of the references to colour in this figure legend, the reader is referred to the Web version of this article.) 


\section{Conclusions}

$U_{37}^{K^{\prime}}$ and $\mathrm{TEX}_{86}{ }^{\mathrm{L}}$ temperatures for three cores from the ECS shelf revealed broadly consistent temporal trends with three distinct intervals corresponding to the gradual establishment and strengthening of the shelf sea circulation system. During the early Holocene (10.0-6.0 ka), the circulation system was not established, characterized by high SST and strong stratification. During the time interval of 6.0-1.0/2.0 $\mathrm{ka}$, the initial establishment of the shelf sea circulation system caused a decrease in SST and weaker stratification. Since 2.0/1.0 ka, the circulation system was strengthened and generated a stronger ECS cold eddy, resulting in an abruptly decrease of SST and much weaker stratification. We attribute the late Holocene strengthening of the surface circulation system in the ECS shelf to the increased El Niño events.

However, the temperature decreases during the late Holocene showed significant spatial heterogeneity. This was most likely caused by the spatial influences of the ECS cold eddy, which was first enhanced in the middle around core site $\mathrm{F} 10 \mathrm{~B}$ at $2.0 \mathrm{ka}$, and then expanded to affect the surrounding area (B3-1A and F11A) at $1.0 \mathrm{ka}$.

\section{Acknowledgements}

We thank Li Li for technical assistance in the organic geochemical analyses and Pan Gao for help with the radiocarbon dating. This work was supported by the National Key Research and Development Program of China (Grant NO. 2016YFA0601403), by the National Natural Science Foundation of China (Grant No. 41641048, 4130966), the “111" Project (No. B13030). This is MCTL contribution \#157.

\section{References}

Alexander, C.R., DeMaster, D.J., Nittrouer, C.A., 1991. Sediment accumulation in a modern epicontinental-shelf setting: the Yellow Sea. Mar. Geol. 98, 51-72.

Badejo, A.O., Gal, J., Hyun, S.-m, Yi, H.-I., Shin, K.-H., 2014. Reconstruction of paleohydrological and paleoenvironmental changes using organic carbon and biomarker analyses of sediments from the northern East China Sea. Quat. Int. 344, 211-223.

Belkin, I.M., Cornillon, P.C., Sherman, K., 2009. Fronts in large marine ecosystems. Prog. Oceanogr. 81, 223-236.

Chen, C.T.A., 2009. Chemical and physical fronts in the Bohai, Yellow and east China seas. J. Mar. Syst. 78, 394-410.

Chen, Y., Hu, D., Wang, F., 2004. Long-term variabilities of thermodynamic structure of the east China Sea Cold eddy in summer. Chin. J. Oceanol. Limnol. 22, 224-230.

Dong, L., Li, L., Li, Q., Wang, H., Zhang, C., 2015. Hydroclimate implications of thermocline variability in the southern South China Sea over the past 180,000 yr. Quat. Res. 83, 370-377.

Dykoski, C.A., Edwards, R.L., Cheng, H., Yuan, D.X., Cai, Y.J., Zhang, M.L., Lin, Y.S., Qing, J.M., An, Z.S., Revenaugh, J., 2005. A high-resolution, absolute-dated Holocene and deglacial Asian monsoon record from Dongge Cave, China. Earth Planet. Sci. Lett. 233, 71-86.

Elling, F.J., Könneke, M., Lipp, J.S., Becker, K.W., Gagen, E.J., Hinrichs, K.-U., 2014 Effects of growth phase on the membrane lipid composition of the thaumarchaeon Nitrosopumilus maritimus and their implications for archaeal lipid distributions in the marine environment. Geochimica Cosmochim. Acta 141, 579-597.

Gang, W., Jian, L., Sun, S., 2010. A preliminary study of the centercs location and interseasonal variabilities of the cold eddy in East China sea. Adv. Earth Sci. 25, 184-192 (in Chinese).

Ge, H., Zhang, C., Li, J., Versteegh, G.J., Hu, B., Zhao, J., Dong, L., 2014. Tetraether lipids from the southern Yellow Sea of China: implications for the variability of East Asia winter monsoon in the holocene. Org. Geochem. 70, 10-19.

Giraudeau, J., Grelaud, M., Solignac, S., Andrews, J., Moros, M., Jansen, E., 2010. Millennial-scale variability in Atlantic water advection to the Nordic Seas derived from Holocene coccolith concentration records. Quat. Sci. Rev. 29, 1276-1287.

Hao, J., Chen, Y., Wang, F., 2012. Long-term variability of the sharp thermocline in the Yellow and east China seas. Chin. J. Oceanol. Limnol. 30, 1016-1025.

Hickox, R., Belkin, I., Cornillon, P., Shan, Z., 2000. Climatology and seasonal variability of ocean fronts in the East China, Yellow and Bohai Seas from satellite SST data. Geophys. Res. Lett. 27, 2945-2948.

Hopmans, E.C., Weijers, J.W.H., Schefuß, E., Herfort, L., Sinninghe Damsté, J.S. Schouten, S., 2004. A novel proxy for terrestrial organic matter in sediments based on branched and isoprenoid tetraether lipids. Earth Planet. Sci. Lett. 224, 107-116.

Hu, B., Yang, Z., Qiao, S., Zhao, M., Fan, D., Wang, H., Bi, N., Li, J., 2014. Holocene shifts in riverine fine-grained sediment supply to the East China Sea Distal Mud in response to climate change. Holocene 24, 1253-1268.

Hu, B., Yang, Z., Zhao, M., Saito, Y., Fan, D., Wang, L., 2012. Grain size records reveal variability of the east Asian winter monsoon since the middle holocene in the central Yellow Sea mud area, China. Sci. China Earth Sci. 55, 1656-1668.
Hu, D., 1984. Upwelling and sedimentation dynamics. Chin. J. Oceanol. Limnol. 2, 12-19.

Huang, E., Tian, J., Steinke, S., 2011. Millennial-scale dynamics of the winter cold tongue in the southern South China Sea over the past $26 \mathrm{ka}$ and the East Asian winter monsoon. Quat. Res. 75, 196-204.

Huguet, C., Schimmelmann, A., Thunell, R., Lourens, L.J., Damsté, J.S.S., Schouten, S., 2007. A study of the TEX $\mathrm{B}_{86}$ paleothermometer in the water column and sediments of the Santa Barbara Basin, California. Paleoceanography 22, PA3203.

Hwang, J.H., Van, S.P., Choi, B.-J., Chang, Y.S., Kim, Y.H., 2014. The physical processes in the Yellow Sea. Ocean Coast. Manag. 112, 449-457.

Inoue, N., 1975. Bottom current on the continental shelf of the East China Sea. Ocean Sky 51, 5-12 (in Japanese).

Jennings, A., Andrews, J., Wilson, L., 2011. Holocene environmental evolution of the SE Greenland shelf north and South of the Denmark strait: irminger and east Greenland current interactions. Quat. Sci. Rev. 30, 980-998.

Jian, Z., Wang, P., Saito, Y., Wang, J., Pflaumann, U., Oba, T., Cheng, X., 2000. Holocene variability of the Kuroshio current in the Okinawa Trough, northwestern Pacific Ocean. Earth Planet. Sci. Lett. 184, 305-319.

Kim, J., Van der Meer, J., Schouten, S., Helmke, P., Willmott, V., Sangiorgi, F., Koç, N., Hopmans, E.C., Damsté, J.S.S., 2010. New indices and calibrations derived from the distribution of crenarchaeal isoprenoid tetraether lipids: implications for past sea surface temperature reconstructions. Geochimica Cosmochim. Acta 74, 4639-4654.

Kim, J.M., Kucera, M., 2000. Benthic foraminifer record of environmental changes in the Yellow Sea (Hwanghae) during the last 15,000 years. Quat. Sci. Rev. 19, 1067-1085.

Koutavas, A., Olive, G.C., Lynch-Stieglitz, J., 2006. Mid-Holocene El Niño-Southern Oscillation (ENSO) attenuation revealed by individual foraminifera in eastern tropical Pacific sediments. Geology 34, 993-996.

Laskar, J., Robutel, P., Joutel, F., Gastineau, M., Correia, A., Levrard, B., 2004. A longterm numerical solution for the insolation quantities of the Earth. Astron. AstroPhys. 428, 261-285.

Lee, H.J., Chough, S.K., 1989. Sediment distribution, dispersal and budget in the Yellow Sea. Mar. Geol. 87, 195-205.

Lee, M.-a., Chang, Y., Shimada, T., 2014. Seasonal evolution of fine-scale sea surface temperature fronts in the East China Sea. Deep Sea Res. Part II Top. Stud. Oceanogr. 119, 20-29.

Li, D., Zhao, M., Tian, J., Li, L., 2013. Comparison and implication of TEX ${ }_{86}$ and $\mathrm{U}_{37}{ }^{\mathrm{K}}$ temperature records over the last $356 \mathrm{kyr}$ of ODP Site 1147 from the northern South China Sea. Palaeogeogr. Palaeoclimatol. Palaeoecol. 376, 213-223.

Li, G., Sun, X., Liu, Y., Bickert, T., Ma, Y., 2009a. Sea surface temperature record from the north of the East China Sea since late Holocene. Chin. Sci. Bull. 54, 4507-4513.

Li, H., Yuan, Y., 1992. On the formation and maintenance mechanisms of the cold water mass of the Yellow Sea. Chin. J. Oceanol. Limnol. 10, 97-106.

Li, T., Nan, Q., Jiang, B., Sun, R., Zhang, D., Li, Q., 2009b. Formation and evolution of the modern warm current system in the East China Sea and the Yellow Sea since the last deglaciation. Chin. J. Oceanol. Limnol. 27, 237-249.

Lie, H.-J., Cho, C.-H., 2016. Seasonal circulation patterns of the Yellow and East China Seas derived from satellite-tracked drifter trajectories and hydrographic observations. Prog. Oceanogr. 146, 121-141.

Lopes dos Santos, R.A., Prange, M., Castañeda, I.S., Schefuß, E., Mulitza, S., Schulz, M., Niedermeyer, E.M., Sinninghe Damsté, J.S., Schouten, S., 2010. Glacial-interglacial variability in Atlantic meridional overturning circulation and thermocline adjustments in the tropical North Atlantic. Earth Planet. Sci. Lett. 300, 407-414.

Lim, D.I., Jung, H.S., Choi, J.Y., Yang, S., Ahn, K.S., 2006. Geochemical compositions of river and shelf sediments in the Yellow Sea: grain-size normalization and sediment provenance. Cont. Shelf Res. 26, 15-24.

Lin, Y., Wei, K., Lin, I., Yu, P., Chiang, H., Chen, C., Shen, C., Mii, H., Chen, Y., 2006. The Holocene Pulleniatina Minimum Event revisited: Geochemical and faunal evidence from the Okinawa Trough and upper reaches of the Kuroshio current. Mar. Micropaleontol. 59, 153-170.

Liu, J., Milliman, J.D., Gao, S., Cheng, P., 2004. Holocene development of the Yellow River's subaqueous delta,North Yellow Sea. Mar. Geol. 209, 45-67.

Liu, K., Ding, X., Fu, D., Pan, Y., Wu, X., Guo, Z., Zhou, L., 2007. A new compact AMS system at Peking University. Nucl. Instrum. Methods Phys. Res. B 259, 23-26.

Max, L., Riethdorf, J.R., Tiedemann, R., et al., 2012. Sea surface temperature variability and sea-ice extent in the subarctic northwest Pacific during the past 15,000 years. Paleoceanography 27 (3), 3213-3232.

Mao, X., Shi, J., Zhao, L., Jiang, W., Zhang, P., 2017. Paleo-temperature in the Yellow Sea during the mid-Holocene estimated using a numerical model. Cont. Shelf Res. 143, $118-129$.

Marcott, S.A., Shakun, J.D., Clark, P.U., Mix, A.C., 2013. A reconstruction of regional and global temperature for the past 11,300 years. Science 339, 1198-1201.

Mcclymont, E.L., Ganeshram, R.S., Pichevin, L.E., Talbot, H.M., Dongen, B.E.V., Thunell, R.C., Haywood, A.M., Singarayer, J.S., Valdes, P.J., 2012. Sea-surface temperature records of Termination 1 in the Gulf of California: Challenges for seasonal and interannual analogues of tropical Pacific climate change. Paleoceanography 27, PA2202.

Milliman, J.D., Beardsley, R.C., Yang, Z., Richard, L., 1985a. Modern Huanghe-derived muds on the outer shelf of the East China Sea: identification and potential transport mechanisms. Cont. Shelf Res. 4, 175-188.

Milliman, J.D., Shen, H.T., Yang, Z.S., H.Mead, R., 1985b. Transport and deposition of river sediment in the Changjiang estuary and adjacent continental shelf. Cont. Shelf Res. 4, 37-45.

Müller, P.J., Kirst, G., Ruhland, G., von Storch, I., Rosell-Mele, A., 1998. Calibration of the alkenone paleotemperature index $\mathrm{U}_{37}{ }^{\mathrm{k}}$ based on core-tops from the eastern South Atlantic and the global ocean $\left(60^{\circ} \mathrm{N}-60^{\circ} \mathrm{S}\right)$. Geochim. Cosmochim. Acta $62(10)$, 1757-1772.

Moossen, H., Bendle, J., Seki, O., Quillmann, U., Kawamura, K., 2015. North Atlantic 
Holocene climate evolution recorded by high-resolution terrestrial and marine biomarker records. Quat. Sci. Rev. 129, 111-127.

Nakanishi, T., Yamamoto, M., Irino, T., Tada, R., 2012a. Distribution of glycerol dialkyl glycerol tetraethers, alkenones and polyunsaturated fatty acids in suspended particulate organic matter in the East China Sea. J. Oceanogr. 68, 957-970.

Nakanishi, T., Yamamoto, M., Tada, R., ODA, H., 2012b. Centennial-scale winter monsoon variability in the northern East China Sea during the Holocene. J. Quat. Sci. 27, 956-963.

Nan, Q., Li, T., Chen, J., Chang, F., Yu, X., Xu, Z., Pi, Z., 2017. Holocene paleoenvironment changes in the northern Yellow Sea: evidence from alkenone-derived sea surface temperature. Palaeogeogr. Palaeoclimatol. Palaeoecol. 483, 83-93.

Park, Y., Khim, B., 1992. Origin and dispersal of recent clay minerals in the Yellow Sea. Mar. Geol. 104, 205-213.

Power, S.B., Smith, I.N., 2007. Weakening of the Walker Circulation and apparent dominance of El Niño both reach record levels, but has ENSO really changed? Geophys. Res. Lett. 34 L18702.

Prahl, F.G., Muehlhausen, L.A., Zahnle, D.L., 1988. Further evaluation of long-chain alkenones as indicators of paleoceanographic conditions. Geochimica Cosmochim. Acta 52, 2303-2310.

Qin, W., Carlson, L.T., Armbrust, E.V., Devol, A.H., Moffett, J.W., Stahl, D.A., Ingalls, A.E., 2015. Confounding effects of oxygen and temperature on the TEX $_{86}$ signature of marine Thaumarchaeota. Proc. Natl. Acad. Sci. 112, 10979-10984.

Qu, T.d., Hu, D.X., 1993. Upwelling and sedimentation dynamics II. a simple model. Chin. J. Oceanol. Limnol. 11, 289-295.

Renssen, H., Seppä, H., Crosta, X., Goosse, H., Roche, D., 2012. Global characterization of the holocene thermal maximum. Quat. Sci. Rev. 48, 7-19.

Renssen, H., Seppä, H., Heiri, O., Roche, D., Goosse, H., Fichefet, T., 2009. The spatial and temporal complexity of the Holocene thermal maximum. Nat. Geosci. 2, 411-414.

Shi, Y.F., Kong, Z.C., Wang, S.M., Tang, L.Y., Wang, F.B., Yao, T.D., Zhao, X.T., Zhang, P.Y., Shi, S.H., 1992. Climatic variations and important events of Holocene megathermal in China (in Chinese). Sci. Sin. Ser. B 12, 1300-1308.

Song, D., Bao, X., Wang, X., Xu, L., Lin, X., Wu, D., 2009. The inter-annual variability of the Yellow Sea Warm Current surface axis and its influencing factors. Chin. J. Oceanol. Limnol. 27, 607-613.

Stuiver, M., Reimer, P.J., Bard, E., Beck, J.W., Burr, G.S., Hughen, K.A., Kromer, B., McCormac, G., Van Der Plicht, J., Spurk, M., 1998. INTCAL98 radiocarbon age calibration, 24,000-0 cal BP. Radiocarbon 40, 1041-1083.

Tao, S., Xing, L., Luo, X., Wei, H., Liu, Y., Zhao, M., 2012. Alkenone distribution in surface sediments of the southern Yellow Sea and implications for the $U_{37}{ }^{k_{1}}$ thermometer. Geo Mar. Lett. 32, 61-71.

Trommer, G., Siccha, M., Rohling, E.J., Grant, K., Van der Meer, M.T., Schouten, S. Hemleben, C., Kucera, M., 2010. Millennial-scale variability in Red Sea circulation in response to Holocene insolation forcing. Paleoceanography 25 PA3203.

Wang, L., Li, J., Lu, H., Gu, Z., Rioual, P., Hao, Q., Mackay, A.W., Jiang, W., Cai, B., Xu, B., Han, J., Chu, G., 2012. The East Asian winter monsoon over the last 15,000 years: its links to high-latitudes and tropical climate systems and complex correlation to the summer monsoon. Quat. Sci. Rev. 32, 131-142.

Wang, L., Yang, Z., Zhang, R., Fan, D., Zhao, M., Hu, B., 2011. Sea surface temperature records of core ZY2 from the central mud area in the South Yellow Sea during last 6200 years and related effect of the Yellow Sea Warm Current. Chin. Sci. Bull. 56, 1588-1595.
Wanner, H., Beer, J., Bütikofer, J., Crowley, T.J., Cubasch, U., Flückiger, J., Goosse, H., Grosjean, M., Joos, F., Kaplan, J.O., 2008. Mid-to Late Holocene climate change: an overview. Quat. Sci. Rev. 27, 1791-1828.

Wanner, H., Solomina, O., Grosjean, M., Ritz, S.P., Jetel, M., 2011. Structure and origin of Holocene cold events. Quat. Sci. Rev. 30, 3109-3123.

Warden, L., Van der Meer, M.T., Moros, M., Damsté, J.S.S., 2016. Sedimentary alkenone distributions reflect salinity changes in the Baltic Sea over the Holocene. Org. Geochem. 102, 30-44.

Xiang, R., Yang, Z., Saito, Y., Fan, D., Chen, M., Guo, Z., Chen, Z., 2008. Paleoenvironmental changes during the last 8400 years in the southern Yellow Sea: benthic foraminiferal and stable isotopic evidence. Mar. Micropaleontol. 67, 104-119.

Xing, L., Jiang, Y., Yuan, Z., Zhang, H., Li, L., Zhou, L., Zhao, M., 2013. Holocene temperature records from the East China sea mud area southwest of the Cheju Island reconstructed by the U37K' and TEX86 paleothermometers. J. Ocean Univ. China 12, $599-604$.

Xing, L., Sachs, J.P., Gao, W., Tao, S., Zhao, X., Li, L., Liu, Y., Zhao, M., 2015. TEX 86 palaeothermometer as an indication of bottom water temperature in the Yellow Sea. Org. Geochem. 86, 19-31.

Xing, L., Zhao, M., Zhang, H., Zhao, X., Yang, Z., Liu, C., 2012. Biomarker evidence for paleoenvironmental changes in the southern Yellow Sea over the last 8200 years. Chin. J. Oceanol. Limnol. 30, 1-11.

Xing, L., Zhao, M., Zhang, T., Yu, M., Duan, S., Zhang, R., Huh, C.-A., Liao, W.-H., Feng, X., 2016. Ecosystem responses to anthropogenic and natural forcing over the last 100 years in the coastal areas of the East China Sea. Holocene 26, 1-9.

Xu, X., Oda, M., 1999. Surface-water evolution of the eastern East China Sea during the last 36,000 years. Mar. Geol. 156, 285-304.

Yamamoto, M., Kishizaki, M., Oba, T., Kawahata, H., 2013. Intense winter cooling of the surface water in the northern Okinawa Trough during the last glacial period. J. Asian Earth Sci. 69, 86-92.

Yuan, D., Hsueh, Y., 2010. Dynamics of the cross-shelf circulation in the Yellow and east China seas in winter. Deep Sea Res. Part II Top. Stud. Oceanogr. 57, 1745-1761.

Yuan, Z., Xing, L., Li, L., Zhang, H., Xiang, R., Zhao, M., 2013. Biomarker records of phytoplankton productivity and community structure changes during the last 14000 years in the mud area southwest off Cheju Island, East China Sea. J. Ocean Univ. China 12, 611-618.

Zhang, Y.G., Zhang, C.L., Liu, X.-L., Li, L., Hinrichs, K.-U., Noakes, J.E., 2011. Methane Index: a tetraether archaeal lipid biomarker indicator for detecting the instability of marine gas hydrates. Earth Planet. Sci. Lett. 307, 525-534.

Zhao, M., Mercer, J.L., Eglinton, G., Teece, M., 2006. Comparative molecular biomarker assessment of phytoplankton paleoproductivity for the last 160kyr off Cap Blanc, NW Africa. Org. Geochem. 37, 72-97.

Zhao, M., Ding, L., Xing, L., Qiao, S., Yang, Z., 2014. Major mid-late Holocene cooling in the East China Sea revealed by an alkenone sea surface temperature record. J. Ocean Univ. China 13, 935-940.

Zhao, X., Tao, S., Zhang, R., Zhang, H., Yang, Z., Zhao, M., 2013. Biomarker records of phytoplankton productivity and community structure changes in the Central Yellow Sea mud area during the Mid-late Holocene. J. Ocean Univ. China 12, 639-646.

Zhao, Y., Yu, Z., Zhao, W., 2011. Holocene vegetation and climate histories in the eastern Tibetan Plateau: controls by insolation-driven temperature or monsoon-derived precipitation changes? Quat. Sci. Rev. 30, 1173-1184. 